\title{
Use of Bifidobacterium bifidum in the manufacture of bifidus milk and its antibacterial activity
}

\author{
AK Misra, RK Kuila \\ Department of Dairy Bacteriology, Bidhan Chandra Krishi Viswavidyalaya \\ (WB Agriculture University), Mohanpur 741 252, Nadia, West Bengal, India
}

(Received 8 April 1991; accepted 21 October 1991)

\begin{abstract}
Summary - A method to prepare bifidus milk on a commercial basis was standardised by addition of $10 \%$ inoculum of Bifidobacterium bifidum NDRI to $9 \%$ reconstituted skim milk $(0.5 \%$ fat, $8.7 \%$ non-fat solids) heated at $95^{\circ} \mathrm{C}$ for $30 \mathrm{~min}$ and incubated at $37^{\circ} \mathrm{C}$ for $18 \mathrm{~h}$. The product was able to meet all the criteria regarding technological and dietetic properties required in a quality product. The effect of various factors influencing the antibacterial activity of bifidus milk against 4 test organisms viz Escherichia coli, Shigella dysenteriae, Staphylococcus aureus and Bacillus cereus was determined. There was a significant variation $(P<0.05)$ in the antibacterial activity of bifidus milk made from various types of milk (reconstituted skim milk, cow milk, buffalo milk, reconstituted infant food) and with various types of heat treatment. Reconstituted skim milk was recommended for preparation of bifidus milk. Heating of milk to sterilization temperature or at $95^{\circ} \mathrm{C}$ for $30 \mathrm{~min}$ had a maximum effect on antibacterial activity. There was no significant variation $(P>0.05)$ in the antibacterial activity at different levels of inoculum (5.10 and $15 \%)$ or due to varying concentrations of sugar. Incubation at $37^{\circ} \mathrm{C}$ showed highest inhibitory activity. Bifidus milk had a minimum storage life of 3 weeks under refrigeration, retaining a sufficiently good taste and the requisite amount of microbial population $\left(10^{8} \mathrm{cfu} / \mathrm{g}\right)$ to be potentially beneficial.
\end{abstract}

Bifidobacterium / bifidus milk / antibacterial activity

Résumé - Fabrication et activité antibactérienne de lait au bifidus préparé en utilisant Bifidobacterium bifidum. Un lait au bifidus a été préparé industriellement par addition de $10 \%$ d'inoculum de Bifidobacterium bifidum NDRI à $9 \%$ de lait écrémé reconstitué $(0,5 \%$ de matière grasse, $8,7 \%$ de matière sèche non grasse) chauffé à $95^{\circ} \mathrm{C} / 30 \mathrm{~min}$, et incubé à $37^{\circ} \mathrm{C}$ pendant $18 \mathrm{~h}$. Le produit présentait toutes les propriétés technologiques et diétiques requises pour un produit de qualité. L'effet de plusieurs facteurs influençant l'activité antibactérienne du lait au bifidus contre 4 types de microorganismes, à savoir Escherichia coli, Shigella dysenteriae, Staphylococcus aureus et Bacillus cereus, a été déterminé. Une variation significative $(\mathrm{P}<0,05)$ de l'activité antibactérienne du lait au bifidus était observée entre les différents types de lait (lait écrémé reconstitué, lait de vache, lait de bufflesse, lait infantile reconstitué) et entre les traitements thermiques. Le lait écrémé reconstitué était recommandé pour la préparation de lait au bifidus. Le chauffage du lait à des températures de stérilisation ou à $95^{\circ} \mathrm{C} / 30 \mathrm{~min}$ avait l'effet maximal sur l'activité antibactérienne. Par contre, les niveaux d'inoculation $(5,10$ et $15 \%)$ et la teneur en sucre n'avaient pas d'influence significative $(\mathrm{P}>$ $0,05)$. L'activité inhibitrice maximale était observée avec une incubation à $37^{\circ} \mathrm{C}$. Après 3 semaines de conservation au réfrigérateur, le goût et le niveau de population microbienne (108 ufc/g) du lait au bifidus étaient considérés comme satisfaisant aux critères requis pour l'alimentation infantile. 


\section{INTRODUCTION}

Bifodogenic microflora have been studied in various countries with a view to utilizing them in the manufacture of various fermented milk products, fresh cheese and dried milks for human nutrition. Regular consumption of these products can have a number of advantages as they contain physiological body-related bacteria (Sandine et al, 1972), have a generally larger content of $L(+)$ lactic acid (Klupsch, 1983), correct various types of gastrointestinal disorders and maintain a favourable balance among the indigenous intestinal microflora (Schaedler et al, 1965).

The technology of bifidus culture in the milk processing industry and the usability of bifidus culture in the manufacture of fermented milks was first described by Schuler-Malyoth et al (1968). Successive efforts in optimizing qualities of bifidusbased fermented milks have also been reported (Kosikowa, 1978; Marshall et al, 1982; Collins and Hall, 1984; Goh et al, 1986), but the product obtained varied from one strain of starter culture to another. In addition there is little information on the anti-bacterial properties of these fermented milks.

The present communication includes a report on the preparation of bifidus milk and assessment of its antibacterial activity as well as its acceptability to consumers.

\section{MATERIALS AND METHODS}

\section{Source and maintenance of cultures}

Bifidobacterium bifidum NDRI and test cultures of pathogenic organisms, viz Bacillus cereus, E coli, Shigella dysenteriae and Staphylococcus aureus were obtained from the National Collec- tion of Dairy Organisms, National Dairy Research Institute, Karnal, India.

$B$ bifidum was maintained in sterile skim milk medium supplemented with $1 \%$ dextrose and $0.1 \%$ yeast extract. The pathogenic test cultures were maintained on nutrient agar slants (Oxoid) and were activated by 3 successive transfers at 24-h intervals in nutrient broth.

\section{Preparation of bifidus milk}

The method of Nahaisi and Robinson (1985) was adopted with minor modifications to prepare a drink for direct consumption through bottle feeding for infants (fig 1).

The effect of some of the factors such as: i), type of milk, viz reconstituted skim milk, cow milk, buffalo milk and reconstituted infant milk food; ii), heat treatment, viz $121^{\circ} \mathrm{C}$ for $15 \mathrm{~min}$, $85^{\circ} \mathrm{C}$ for $30 \mathrm{~min}, 95^{\circ} \mathrm{C}$ for $30 \mathrm{~min}$ and steaming for $30 \mathrm{~min}$; iii), size of inoculum, viz 2, 5, 10, 15 and $20 \%$; iv) incubation temperature, viz 32,37 40 and $45^{\circ} \mathrm{C}$; v), concentration of sucrose, viz $0,6,8$, and $12 \%$; and vi) storage at refrigeration temperature $\left(5-8^{\circ} \mathrm{C}\right)$ for $3,10,17,24$ and 30 days - on the antibacterial activity of bifidus milk prepared by Bifidobacterium bifidum NDRI (National Dairy Research Institute) were also examined.

\section{Analysis}

Bifidus milk products were analysed for titratable acidity (ISI, 1960), volatile acidity (Hempeniens and Liska, 1968), lactic acid (Barker and Summerson, 1941), proteolytic activity (Hull, 1947) and combined diacetyl and acetoin (King, 1948). The antibacterial activity of the product was estimated by the modified cup agar assay technique (BSI, 1968). Culture filtrates (or cellfree extracts) were collected by centrifugation at $3000 \mathrm{rpm}$ for $15-20 \mathrm{~min}$. These were passed through a Seitz filter separately. Wells of 5.0 $\mathrm{mm}$ diameter were made on solidified nutrient agar (seeded with the pathogenic test organisms) in each plate, using a sterile hollow borer. With the help of a sterile serological pipette, $0.05 \mathrm{ml}$ of the cell-free extract was transferred to 


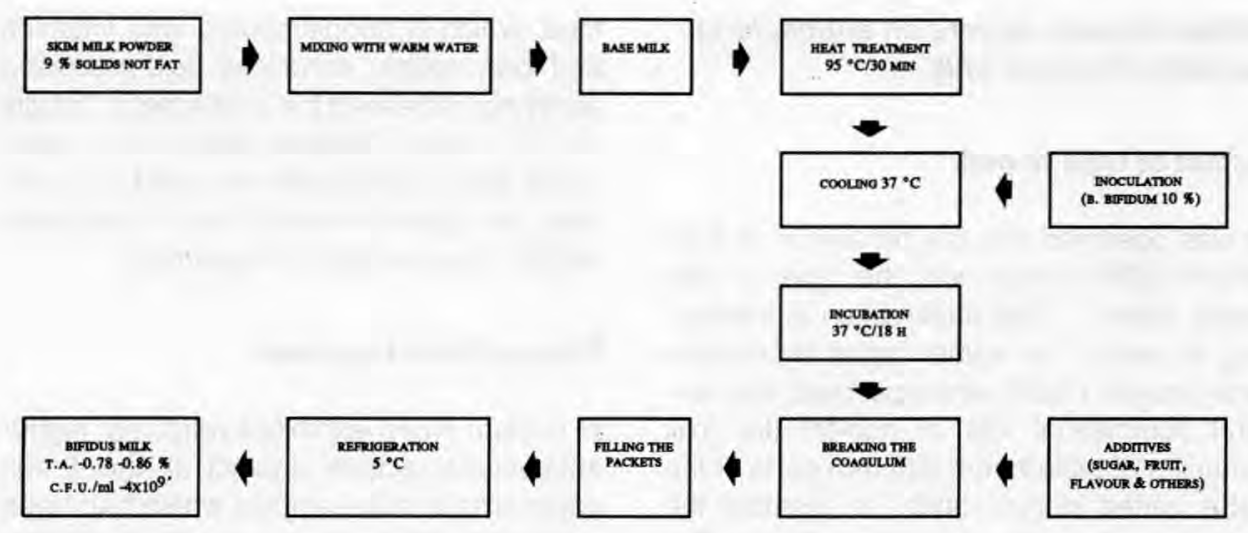

Fig 1. Schematic diagram for the manufacture of bifidus milk.

Diagramme schématique de fabrication de lait fermenté au bifidus.

different wells. The plates were incubated without inverting at $37^{\circ} \mathrm{C}$ for $18-24 \mathrm{~h}$ and the diameters of zones of inhibition formed around the wells were measured. Results were statistically analysed for analysis of variance according to the method of Snedecor and Cochran (1967).

Samples of standardized bifidus milk products, viz bifidus sour milk and bifidus sweetened milk, were subjected to sensory evaluation by a panel of 7 judges using the 9-point hedonic scale (Amerine et al, 1967) and analysed statistically by 2 -way classification.

\section{RESULTS AND DISCUSSION}

\section{Characteristics of the product}

On the basis of the results of different trials, the procedure shown in figure 1 was adopted for the preparation of bifidus milk using single culture of Bifidobacterium bifidum NDRI. The final product had a titratable acidity of $0.78-0.86 \%, 1.9-2.2 \mathrm{ml}$ of volatile acidity, proteolytic activity of 30 $\mathrm{mg} \%$ liberated tyrosine, a mild acidic flavour and a viable count of $4 \times 10^{9} \mathrm{cfu} / \mathrm{ml}$. The product also showed desirable anti- bacterial activity against the 4 test organisms, namely Escherichia coli, Shigella dysenteriae, Staphylococcus aureus and Bacillus cereus. The most important criterion defining the usefulness of bifidus milk for intestinal therapy is the ability of $B$ bifidum to be successfully implanted in the intestine. Several workers have reported that for successful seeding in the intestine, the viable population must be in the range of $10^{8}-10^{9} \mathrm{cells} / \mathrm{ml}$ of the product (Tanaka et al, 1982; Kim, 1988). The viable cell population obtained in the product satisfied this condition. The percent inoculum of $B$ bifidum utilized by many workers ranged between 2-5\%, and the normal time taken for setting was $24 \mathrm{~h}$ (Brown and Townsley, 1970; Marshall et al, 1982). Fonden and Holgersson (1985) characterized Bifidobacterium species as slow cultivators in milk and recommended a larger inoculum $(5-20 \%)$ of starter culture in the final manufacture of the cultured milk. Similar experiences were observed in the present study and $10 \%$ inoculum was found to meet all the criteria regarding technological and dietetic properties required in the product. 


\section{Effect of some factors on antibacterial activity of bifidus milk}

\section{Effect of type of milk}

It was observed that the behaviour of $\mathrm{B} \mathrm{bi}$ fidum NDRI varied with the type of milk used (table 1). This observation is interesting in view of an earlier report by Greene and Jezeski (1957) who observed that several commercial lots of non-fat dry milk samples obtained from different parts of the USA varied in their ability to promote the growth and activity of starter cultures. The acid production in all the types of milk was within the range of $0.81-0.87 \%$ lactic acid and there was a significant variation in the antibacterial activity according to the types of milk used $(P<0.05)$. Reconstituted skim milk ( $0.5 \%$ fat and $8.7 \%$ non-fat solids) and cow milk ( $3.5 \%$ fat and $8.5 \%$ non-fat solids) had a similar effect on the antibacterial activity of $B$ bifidum. Reconstituted infant milk food, which is supplemented with vitamins and iron, neither enhanced acid-producing ability nor increased the antibacterial activity of the culture. Similar observations were made when buffalo milk was used as a medium for growth except that it produced slightly higher acidity in the product.

\section{Effect of heat treatment}

$B$ bifidum NDRI exhibited relatively higher antibacterial activity against all the 4 test organisms in milk samples which had been sterilized at $15 \mathrm{psi}$ for $15 \mathrm{~min}$ (table II). Milk samples heated at $95^{\circ} \mathrm{C}$ for $30 \mathrm{~min}$ produced similar results. As regards production of acid, the highest amount was produced in milk heated at $95^{\circ} \mathrm{C}$ for $30 \mathrm{~min}$. A similar trend was noticed in the case of sterilized milk. These results are consistent with similar observations made by other workers, although there appears to be some divergence of opinion in this respect.

Table I. Effect of various types of milk on the antibacterial activity of bifidus sour milk * Effet de différents types de lait sur l'activité antibactérienne du lait fermenté au bifidus +.

\begin{tabular}{|c|c|c|c|c|c|c|c|}
\hline \multirow[t]{2}{*}{ Type of milk } & \multirow{2}{*}{$\begin{array}{l}\text { Fat } \\
\text { (\%) }\end{array}$} & \multirow{2}{*}{$\begin{array}{l}\text { SNF } \\
\text { (\%) }\end{array}$} & \multirow{2}{*}{$\begin{array}{l}\text { Acidity } \\
(\% \text { LA) }\end{array}$} & \multicolumn{4}{|c|}{ Diameter of zone of inhibition (in $\mathrm{mm}$ ) * } \\
\hline & & & & $\underset{\text { coli }}{E}$ & $\begin{array}{c}\text { Shigella } \\
\text { dysenteriae }\end{array}$ & $\begin{array}{l}\text { Staphylococcus } \\
\text { aureus }\end{array}$ & $\begin{array}{l}\text { Bacillus } \\
\text { cereus }\end{array}$ \\
\hline $\begin{array}{l}\text { Reconstituted } \\
\text { skim milk }\end{array}$ & 0.5 & 8.7 & 0.86 & 11 & 11 & 8.5 & 10.5 \\
\hline Cow milk & 3.5 & 8.5 & 0.81 & 11.5 & 8.5 & 8.0 & 9.5 \\
\hline Buffalo milk & 5.0 & 9.0 & 0.87 & 7.0 & 8.0 & 8.0 & 5.0 \\
\hline $\begin{array}{l}\text { Reconstituted } \\
\text { infant food }\end{array}$ & 3.3 & 8.7 & 0.83 & 8.0 & 8.5 & 6.0 & 9.0 \\
\hline
\end{tabular}

+ Inoculated with $10 \%$ starter and incubated at $37^{\circ} \mathrm{C}$ for $48 \mathrm{~h}$; * included diameter of well (5 mm); NFS: non-fat solids. Amount of supernatant added to well: $0.05 \mathrm{ml}$.

+ Inoculé avec $10 \%$ de levain et incubé à $37^{\circ} \mathrm{C}$ pendant $48 \mathrm{~h}$. " : incluant le diamètre du puits (5 mm); SNF : matière sèche non grasse; $(0,05 \mathrm{ml}$ de surnageant ajouté dans le puits). 
Table II. Effect of heat treatment of milk on the antibacterial activity of bifidus sour milk $\mathbf{k}^{+}$ Effet du traitement thermique du lait sur l'activité antibactérienne du lait fermenté au bifidus'.

\begin{tabular}{lcccccc}
\hline \multirow{2}{*}{$\begin{array}{l}\text { Type of heat } \\
\text { treatment }\end{array}$} & $\begin{array}{c}\text { Acidity } \\
(\% \text { LA) }\end{array}$ & $\begin{array}{c}\text { Total cell } \\
\text { count }(\mathrm{cfu} / \mathrm{ml})\end{array}$ & \multicolumn{4}{c}{ Diameter of zone of inhibition (in mm) * } \\
\cline { 5 - 7 } & & & $\begin{array}{c}\mathrm{E} \\
\text { coli }\end{array}$ & $\begin{array}{c}\text { Shigella } \\
\text { dysenteriae }\end{array}$ & $\begin{array}{c}\text { Staphylococcus } \\
\text { aureus }\end{array}$ & $\begin{array}{c}\text { Bacillus } \\
\text { cereus }\end{array}$ \\
\hline $\begin{array}{l}\text { Sterilization } \\
\left(121^{\circ} \mathrm{C}, 15 \mathrm{psi} /\right.\end{array}$ & 0.87 & $14 \times 10^{8}$ & 11.5 & 11.5 & 8.5 & 11.0 \\
$\begin{array}{l}15 \mathrm{~min}) \\
\text { Steaming }\end{array}$ & 0.84 & $1 \times 10^{8}$ & 8.5 & 11.0 & 9.0 & 10.0 \\
$\begin{array}{l}(30 \mathrm{~min}) \\
95^{\circ} \mathrm{C} \text { for } 30 \mathrm{~min}\end{array}$ & 0.91 & $10 \times 10^{8}$ & 11.0 & 11.0 & 8.5 & 10.5 \\
$85^{\circ} \mathrm{C}$ for $30 \mathrm{~min}$ & 0.85 & $11 \times 10^{8}$ & 8.5 & 8.5 & 8.0 & 9.0 \\
\hline
\end{tabular}

+ Skim milk ( $0.5 \%$ fat, $8.7 \%$ non fat solids) inoculated with $10 \%$ starter and incubated at $37{ }^{\circ} \mathrm{C}$ for $48 \mathrm{~h} ;{ }^{*}$ included diameter of well $(5 \mathrm{~mm})$. Amount of supernatant added to well: $0.05 \mathrm{ml}$.

+ Lait écrémé ( $0,5 \%$ matière grasse, $8,7 \%$ matière sèche non grasse) inoculé avec $10 \%$ de levain et incubé à $37{ }^{\circ} \mathrm{C}$ pendant $48 \mathrm{~h}$. " incluant le diamètre du puits $(5 \mathrm{~mm})(0,05 \mathrm{ml}$ de surnageant ajouté dans le puits).

Foster (1952) and Babel (1967) considered that higher heat treatments at $120^{\circ} \mathrm{C}$ for $15 \mathrm{~min}$ and $85^{\circ} \mathrm{C}$ for $30 \mathrm{~min}$ enhanced acid production, whereas Goh et al (1986) observed a decrease in the acid production of $B$ bifidum ATCC11863 when the milk medium was heated at $95^{\circ} \mathrm{C}$ for 30 min, $121^{\circ} \mathrm{C}$ for $1 \mathrm{~min}$ or $85^{\circ} \mathrm{C}$ for $15 \mathrm{~min}$ than when it was heated at $85^{\circ} \mathrm{C}$ for 30 $\mathrm{min}$. The total colony count of $B$ bifidum was the highest in milk samples which were sterilized, giving a viable count of 14 $\times 10^{8} \mathrm{cfu} / \mathrm{ml}$. This increase in acid production and viable count can be attributed to the increased amounts of usable nitrogen provided due to partial hydrolysis of casein, as suggested by Foster (1952). On statistical analysis, a significant variation in the antibacterial activity of the $B$ bifidum culture in milk was observed with the various types of heat treatment $(P<0.05)$.
Heating of milk to sterilization temperatures and heating at $95^{\circ} \mathrm{C}$ for $30 \mathrm{~min}$ had a similar effect on the antibacterial activity of $B$ bifidum in milk. On the basis of these results, heating of milk at $95^{\circ} \mathrm{C}$ for $30 \mathrm{~min}$ was employed as it could easily be adopted by dairy plants and under household conditions for production of bifidus milk.

\section{Effect of the levels of inoculum}

There was no significant variation in the antibacterial activity of different levels of inoculum of $B$ bifidum culture $(P>0.05)$, but there was a significant relationship of percent inoculum and the acidity produced which was directly related to the total viable count. The antibacterial activity against the 4 test organisms was almost the same at 5, 10 and $15 \%$ levels of inocu- 
lum. Similar observations for 1,2 and $3 \%$ inoculum of $L$ acidophilus have been reported by Gandhi (1978).

\section{Effect of the incubation temperature}

The effect of different incubation temperatures on the antibacterial activity of $B$ bifidum-NDRI in milk as presented in table III showed poor acid production and reduced antibacterial activity at $32{ }^{\circ} \mathrm{C}$. There was no zone of inhibition when tested against E coli and Staphylococcus aureus. As the temperature was raised from 32 to $37^{\circ} \mathrm{C}$ the acid production and antibacterial activity were increased but at $40^{\circ} \mathrm{C}$ antibacterial activity was not exhibited against Shige/la dysenteriae, Staphylococcus aureus and $E$ coli. The optimum temperature for the growth of $B$ bifidum was $37^{\circ} \mathrm{C}$ and thus the maximum production of antibacterial substances was expected at this temperature. Similar results have been reported by Shahani et al (1976) for $L$ acidophilus.

\section{Effect of addition of sugar}

Since bifidus sour milk tastes too bitter for infants, sweetened bifidus milk was prepared using different concentrations of sugar. It was observed that as the level of sugar addition increased there was no significant variation in the antibacterial activity $(P>0.05)$. However, it was observed that the product with $12 \%$ level of sucrose was excellent in taste and had acidity within the desirable limit.

\section{Effect of storage at refrigeration temperature}

Refrigerated storage $\left(5-8{ }^{\circ} \mathrm{C}\right)$ of bifidus sour milk for 30 days indicated that as the storage time increased beyond 3 days there was a decrease in the antibacterial activity against the 4 test organisms, with a sharp decline by the end of second week (fig 2). The total viable count was also found to decrease from $4.1 \times 10^{9} \mathrm{cfu} / \mathrm{ml}$ to.

Table III. Effect of incubation temperature on the antibacterial activity of bifidus sour milk + . Effet de la température d'incubation sur l'activité antibactérienne du lait fermenté du bifidus ${ }^{+}$.

\begin{tabular}{cccccc}
\hline $\begin{array}{l}\text { Incubation } \\
\text { temperature }\left({ }^{\circ} \mathrm{C}\right)\end{array}$ & $\begin{array}{c}\text { Acidity } \\
(\% \mathrm{LA})\end{array}$ & \multicolumn{4}{c}{ Diameter zone of inhibition (in mm) * } \\
\cline { 3 - 6 } & & $\begin{array}{c}\mathrm{E} \\
\text { coli }\end{array}$ & $\begin{array}{c}\text { Shigella } \\
\text { dysenteriae }\end{array}$ & $\begin{array}{c}\text { Staphylococcus } \\
\text { aureus }\end{array}$ & $\begin{array}{c}\text { Bacillus } \\
\text { cereus }\end{array}$ \\
\hline & & - & 7.5 & - & 8.0 \\
32 & 0.56 & 8.5 & 10.0 & 8.0 & 8.0 \\
47 & 0.86 & -.0 & - & - & 10.0 \\
45 & 0.71 & - & - & - & 6.5 \\
\hline
\end{tabular}

+ Skim milk inoculated with $10 \%$ starter and incubated for $48 \mathrm{~h}$; ${ }^{*}$ included diameter of well (5 mm); -; no inhibition observed. Amount of supernatant added: $0.05 \mathrm{ml}$.

+ Lait écrémé inoculé avec $10 \%$ de levain et incubé pendant $48 \mathrm{~h}$; " incluant le diamètre du puits (5 mm); - : pas d'inhibition observée; $(0,05 \mathrm{ml}$ de surnageant ajouté dans le puits). 


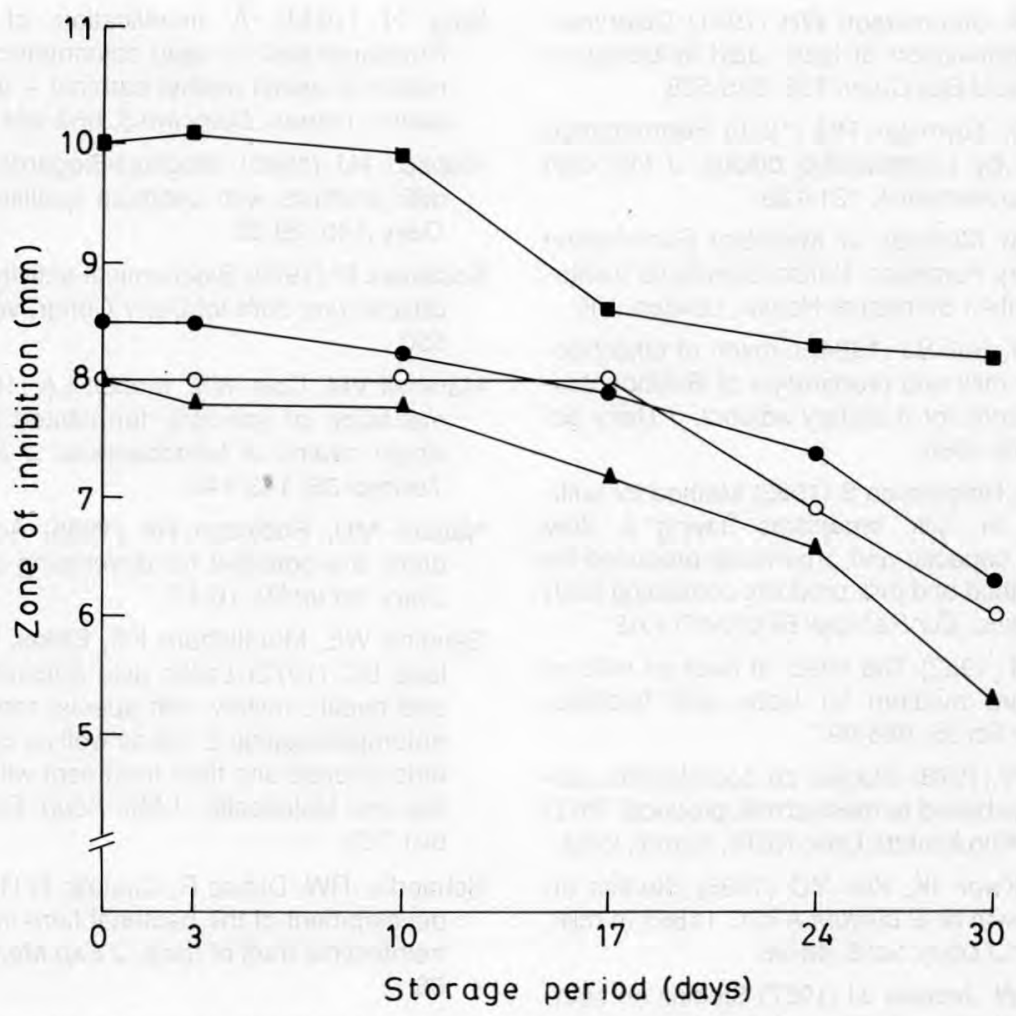

Fig 2. Effect of storage at refrigeration temperature on antibacterial activity of bifidus sour milk. E coli; - Shigella dysenteriae; $\mathbf{\Delta - \Delta}$ Staphylococcus aureus; O-O Bacillus cereus.

Effet de la conservation au réfrigérateur sur l'activité antibactérienne du lait fermenté au bifidus.

$2.1 \times 10^{6} \mathrm{cfu} / \mathrm{ml}$ after 30 days of storage. The product did not have any off-flavour after 30 days of storage, but it tasted very sour. Products stored up to 17 days were good in taste and also had the requisite amount of total viable count $\left(10^{8} \mathrm{cfu} / \mathrm{g}\right)$ to be utilized for implantation in the intestine by direct consumption of bifidus milk.

\section{CONCLUSION}

Sensory evaluation studies revealed that sweetened bifidus milk was preferred over normal bifidus milk. Thus direct consumption of sweetened bifidus milk can be recommended for infants through bottle feeding with the aim of providing viable cells suitable for intestinal implantation.

\section{REFERENCES}

Amerine MA, Pangborn RM, Roessler EM (1967) A Principle of Sensory Evaluation of Foods. Academic Press, New York

Babel FJ (1967) Techniques for cultured products. J Dairy Sci 50, 431-433 
Barker SB, Summerson WH (1941) Colorimetric determination of lactic acid in biological material. J Biol Chem 138, 535-538

Brown CD, Townsley PM (1970) Fermentation of milk by Lactobacillus bifidus. J Inst Can Technol Aliment 3, 121-129

BSI (1968) Methods of Microbial Examination for Dairy Purposes. British Standards Institution, British Standards House, London, UK

Collins EB, Hall BJ (1984) Growth of bifidobacteria in milk and preparation of Bifidobacterium infantis for a dietary adjunct. J Dairy Sci $67,1376-1380$

Fonden R, Holgersson S (1985) Method for cultivating, in milk, organisms having a slow growth capacity and organisms produced by the method and milk products containing such organisms. Eur Pat Appl EP0154614 A2

Foster EM (1952) The effect of heat on milk as a culture medium for lactic acid bacteria. J Dairy Sci 35, 988-997

Gandhi DN (1978) Studies on Lactobacillus acidophilus based fermented milk products. Ph D thesis, Kurukshetra Univ, NDRI, Karnal, India

Goh JS, Kwon IK, Kim YO (1986) Studies on the growth of $B$ bifidum ATCC 11863 in milk. Korean J Dairy Sci 8, 48-56

Greene VW, Jezeski JJ (1957) Studies on starter metabolism. I. The relationship between starter activity and the predrying heat history of reconstituted non fat dry milk solids. J Dairy Sci 40, 1046-1052

Hempeniens WL, Liska BJ (1968) Method for determining volatile acids in cultured dairy products. J Dairy Sci 51, 221-222

Hull ME (1947) Studies on milk protein. II. Colorimetric determination of the partial hydrolysis of the proteins in milk. J Dairy Sci 30 , 881-883

ISI (1960) Indian Standard: 1479 (Part I) Methods of Test for Dairy Industry. Rapid Examination of Milk. Indian Standard Institution, Manak Bhavan, New Delhi, India

Kim SH (1988) Characterization of lactobacilli and bifidobacteria as applied to dietary adjuncts. Cult Dairy Prod J 8, 5-6
King N (1948) A modification of VogesProskauer test for rapid colorimetric determination of acetyl methyl carbinol + diacetyl in butter cultures. Dairy Ind 8, 860-864

Klupsch HJ (1983) Bioghurt-Biogarde-acidified milk products with optimum qualities. $N$ Eur Dairy J 49, 29-32

Kosikowa M (1978) Biochemical activity of Bifidobacterium. 20th Int Dairy Congr, vol E, 549550

Marshall VM, Cole WM, Mabbit LA (1982) Fermentation of specially formulated milk with single strains of bifidobacteria. J Soc Dairy Techno/ 35, 143-144

Nahaisi MH, Robinson RK (1985) Acidophilus drink: the potential for developing countries. Dairy Ind Int 50, 16-17

Sandine WE, Muralidhara KS, Elliker PR, England DC (1972) Lactic acid bacteria in food and health: review with special reference to enteropathogenic $E$ coli as well as certain enteric disease and their treatment with antibiotics and lactobacilli. J Milk Food Technol 35, 691-702

Schaedler RW, Dubos R, Cosiello R (1965) The development of the bacterial flora in the gastrointestinal tract of mice. J Exp Med 122, 59 66

Schuler Malyoth VR, Ruppert A, Muller F (1968) A survey of the theoretical and practical principles of using bifidus cultures in the dairy industry. II. Technology of bifidus culture in the milk processing factory. Milchwissenschaft 23, 554-558

Shahani KM, Vakil JR, Kilara A (1976) Natural antibiotic activity of Lactobacillus acidophilus and bulgaricus. 1. Cultural conditions for the production of antibiosis. Cult Dairy Prod J11, 14-17

Snedecor GW, Cochran WG (1967) Statistical Methods. Oxford and IBH Publ Co, Calcutta, India

Tanaka $M$, Iwanami $T$, Arai $K$, Nakagawa $K$, Joko K, Muroto I, Yamaduki M (1982) Cultured milk production method. German Federal Republic Pat DE, 3048-438 